'No taxation without hypothecation': towards an improved understanding of the acceptability of an environmental tax reform ${ }^{1}$

Kris Bachus ${ }^{\text {a* }}$

Luc Van Ootegem ${ }^{\mathrm{a}, \mathrm{b}}$

Elsy Verhofstadt ${ }^{\mathrm{b}}$

${ }^{a}$ University of Leuven, HIVA - KU Leuven, Parkstraat 47 box 5300, B-3000 Leuven, Belgium, kris.bachus@kuleuven.be, +32/16.32.31.25

b SHERPPA - Ghent University, Sint-Pietersplein 6, B-9000 Ghent, Belgium, Luc.vanootegem@ugent.be, Elsy.verhofstadt@ugent.be.

${ }^{1}$ A previous version of this paper was published as a chapter of a $\mathrm{PhD}$ dissertation (Bachus, 2017). 


\title{
'No taxation without hypothecation': towards an improved understanding of the acceptability of an environmental tax reform
}

\begin{abstract}
Although it is widely acknowledged that taxation is a powerful instrument for combating environmental problems, environmental taxation is still underused. Public acceptability of regulatory taxes appears to be low, to the extent that a trade-off between the acceptability and the efficiency of policy instruments can be observed. This paper examines the determinants and conditions for public support and willingness to pay for environmental taxation, based on survey data of 1308 citizens. The results show that education and environmental awareness are determinants for support, and that initial low support can be significantly improved by earmarking the tax revenues to the environment. Other ways of revenue recycling, such as an environmental tax reform, can be ranked based on acceptability. We call this ranking the 'Ladder of Acceptability of Revenue Recycling Options' (LARRO). Well-chosen design options for the environmental tax reform can further improve its acceptability.
\end{abstract}

Keywords: Environmental taxation; Acceptability; Public acceptance; Public support; Environmental tax reform; Revenue recycling.

\section{Introduction}

Today it is widely accepted that taxation is a powerful instrument for combating complex environmental problems, such as climate change (Aidt, 2010). However, policy processes aimed at implementing environmental taxes often fail, for many reasons (Heres, Kallbekken, \& Galarraga, 2013). The literature devotes quite some attention to the role of lobbying by NGOs and businesses in policy processes aiming at implementing environmental taxes (Cherry, Kallbekken, \& Kroll, 2014). However, another factor that is thought to thwart large-scale implementation of environmental (Pigouvian) taxation is public acceptability (Vandyck and Van Regemorter, 2014). Taxation as an instrument aimed at environmental behavioural change has always suffered from low acceptance with the public (Baranzini and Carattini, 2017). When the revenues of taxes are used for environmental spending or reducing other taxes, public support significantly increases but still remains limited (Hsu, Walters, \& Purgas, 2008). 
Although the exact reasons for this aversion is still under study, factors found to have an impact include the perceived (low) effectiveness of environmental taxation, the coerciveness of the instrument and psychological factors such as fiscal illusion (Baranzini, Caliskan, \& Carattini, 2014; Houdek and Koblovský, 2015).

This paper first reviews the theoretical and empirical literature on the determinants of public support for environmental taxes (ETX) and environmental tax reform (ETR). The difference between these two terms is that an $\mathrm{ETR}^{2}$ adds how the revenues of the ETX will be spent. Second, it draws several hypotheses from the literature to test new determinants to explain public support and to find more detailed evidence regarding existing claims. The data are drawn from a unique large scale quantitative survey on the acceptance of environmental taxation and environmental tax reform carried out in Flanders, Belgium. Third, the paper uses the empirical results to propose policy recommendations on how to overcome the acceptability barrier to environmental fiscal reform. This study exclusively focuses on acceptance by citizens, not by firms or other societal actors that may also influence policy-making.

In this paper, support, acceptance and acceptability of environmental taxation are used interchangeably with 'willingness to pay' (WTP). The term 'support' is used more often in social acceptability studies, while WTP in environmental economics is primarily used in the context of willingness to pay for improved environmental quality or less pollution. WTP can be regarded as an indirect measure of support for pricing policy instruments such as taxation (Ivanova and Tranter, 2004).

The paper first turns to the state of the art of the literature. It then proposes a number of hypotheses on the acceptance of environmental taxation (ETX). It continues with a description

\footnotetext{
2 An environmental tax reform (ETR), or green tax reform, is the process of shifting the tax burden from employment, income and investment, to pollution, resource depletion and waste (OECD, 1997). An ETR consists of two components: an increase in ETX, and a decrease in other taxes. Such a reform often (but not necessarily) aims at revenue-neutrality for the government.
} 
of the survey carried out in Flanders, after which the results are presented. We end with conclusions, policy recommendations and ideas for future research.

\section{Theoretical and empirical state of the art}

The topic of support for environmental taxation does not rely on a distinct theoretical school or model. Theoretical studies touching upon the issue build on various disciplines, including economics (neoclassical and Pigouvian theory, public choice theory, behavioural economics), political science (instrument choice theory) and psychology. The many empirical studies either draw their hypotheses from those theoretical strands or approach the topic in an ad-hoc manner, examining potential determinants of acceptability without clear roots in theory. A central concept for understanding (lack of) public support for environmental tax reform (ETR) is tax aversion. Because of its importance, tax aversion is treated in a separate section (2.1). In section 2.2, other relevant theories are elaborated and in section 2.3 we summarize the empirical literature on the acceptance of environmental taxation (ETX).

\section{Tax aversion}

Several large-scale value surveys show that citizens tend to attach great value to a healthy environment and that they consider environmental degradation to be an important problem (Melis, Elliot, \& Shryane, 2014). Moreover, there appears to be a positive link between environmental concern and willingness to pay (WTP) for a clean environment (Pagiaslis and Krontalis, 2014).

In contemporary policy-making, taxation has three goals (Avi-Yonah, 2007). The first goal of taxation is to raise revenue to finance government functions, such as the provision of public goods. The second goal is redistribution, the transfer of part of the revenues to reduce inequality. The third goal of taxation is regulation of behaviour: citizens and business are 
incentivised or discouraged to behave in a certain way (Avi-Yonah, 2010). Environmental policy is probably the field in which regulatory taxation ${ }^{3}$ has gained the most ground. Pigou (1920) highlighted the theoretical advantages of taxation as an instrument to address market failures and make private actors internalise external environmental costs. More recently, scholars have presented a (Pigouvian) carbon tax as a potentially efficient instrument for climate change mitigation (Avi-Yonah and Uhlmann, 2009; Newell and Pizer, 2003; Zhang, Wang, Liang, \& Chen, 2016). ${ }^{4}$

Notwithstanding the high efficiency, the use of regulatory taxation such as environmental taxes (ETX) is not very widespread (Kallbekken, Kroll, \& Cherry, 2011; Oh and Svendsen, 2015). The alleged underuse is related to the low willingness to pay for the environment and the unpopularity of environmental taxation with the public. People are often opposed to the implementation of an ET, even when they support the objective behind it (Beuermann and Santarius, 2006; Kallbekken and Aasen, 2010).

In general, part of the unpopularity of the tax instrument is due to the fact that coercive policy instruments, such as a tax or a ban, are less appealing to people than positive instruments, such as a subsidy or suasion instruments (Hood, 1983). McCaffery and Baron (2003a) call this phenomenon 'penalty aversion'. Subsidies are a voluntary instrument, whereas taxation and command-and-control instruments 'restrict people's freedom of choice and force people to change their own behavior' (Steg, Dreijerink, \& Abrahamse, 2006, p. 94). To Stern, Dietz, \& Kalof (1993), this coerciveness aversion is a simple expression of the fact that people act out

\footnotetext{
${ }^{3}$ We use the term 'regulatory' in the broad sense, following the American school definition: 'Regulation is any attempt by the government to control the behavior of citizens' (Meier, 1985). In the standard English school, the term is defined more narrowly as all prohibitions and obligations imposed by government (Vedung, 1998).

${ }^{4}$ Although in a second-best world with uncertainty, the efficiency of environmental taxes is subject to certain conditions, such as the slope of the marginal abatement curve and the marginal damage curve (Perman, Common, Maddison, \& McGrilvray, 2003).
} 
of self-interest. According to Attari et al. (2009, p. 1702), 'hard regulations evoke psychological reactance, and individuals look for ways to re-establish their lost freedom'.

However, the dislike of coercive policy instruments does not provide a conclusive explanation for the limited support for Pigouvian taxation. Taxation seems to arouse even more opposition than command-and-control instruments. Franzen and Meyer (2010) found that consumers' willingness to pay higher prices for the environment was significantly higher than their willingness to pay higher taxes for the environment, although those two options would have identical implications for them in practice. According to Clinch et al. (2006, p. 968), taxes have 'particularly negative connotations'. In the climate change related cap-or-tax debate, AviYonah and Uhlmann (2009, p. 7) call an emissions trading scheme more politically feasible 'simply because it is not labelled a tax'. Nordhaus (2007) takes this conclusion even one step further, attaching the label 'almost a four letter word' to a tax. (Cherry, Kallbekken, \& Kroll, 2017) and Kallbekken, et al. (2011) found that people would sometimes vote against a tax reform even when it is to their benefit, a phenomenon which is referred to as tax aversion. Insights from behavioural economics (see section 2.2) provide some explanations for this seemingly irrational - citizen attitude. In addition, two hypotheses from the literature may add to the understanding of tax aversion, which tends to be even greater in the context of the environment than in other fields (Green Fiscal Commission, 2009). First, contrary to what studies find, people have a tendency to believe that Pigouvian taxation is not effective in changing behaviour to the benefit of the environment, or they at least underestimate its effects (Baranzini, et al., 2014). Second, people do not believe that government will spend the revenues from the environmental tax in an optimal way. These and other hypotheses explaining low acceptance of environmental taxation are further detailed in section 2.3. 


\section{Other explanations for low acceptance of environmental taxation}

The theory of using taxation to internalize externalities traces back to the work of Pigou (1920) and has been further elaborated by many other authors, such as Baumol and Oates (1988) and Coase (1960). The theory of Pigouvian taxation is based on the neoclassical theory of rational choice, which assumes that economic agents act in a rational way according to their individual preferences in such a way that their utility (or profit for companies) is maximized. However, the assumptions of the neoclassical model have since long been under attack by a variety of theoretical schools, including public choice theory, for having a 'romantic and illusory' notion of how governments function (Buchanan and Tollison, 1984). Public choice scholars claim that rational politicians let themselves be influenced by the preferences of the actors who are subject to the policy, and that decision-makers will be wary of implementing policies that go against the desire of the 'median voter' (Peters, 1991). This situation would engender suboptimal (instrument) choices which can be regarded as government failures (Caplan, 2007).

Public choice theory, in turn, has been criticized for making a caricature of individuals (Cullis and Jones, 1998). Disciplines such as economic psychology and behavioural economics explain the 'failures' of individuals by arguing that people, including decision-makers, are facing bounded rationality (Simon, 1955). Decision-makers do not maximize (benefits over costs) but aim to satisfice, or aim for 'good enough'. They still seek rationality, but resort to unavoidable simplification to reduce complexity and keep matters manageable. More specifically, they use heuristics and are prone to biases when making decisions under uncertainty (Kahneman, 2003). Applied to environmental taxation, some of these biases contribute to explaining why support for environmental taxation and environmental tax reform is limited. The observation of these biases does not mean that the rationality paradigm of neoclassical economics is invalid, but complements it by adding that rationality is far from absolute and in some cases even dominated by heuristics and cognitive biases. The first of seven 
biases is fiscal illusion (Wagner, 1976): people's cognitive skills are limited, and even modestly complex tax systems or reforms cause them to make systematic optimization errors (Chetty, Looney, \& Kroft, 2009; McCaffery and Baron, 2003a). For example, in case of an ETR, people clearly see and feel the environmental tax, but they do not (or much less) see or consider the benefits they get from the revenue recycling. For this reason, tax reforms with an environmental tax element and a labour tax element may just be too complex to grasp for most citizens. A second bias, related to the first, is the role of salience. People tend to dislike transparent taxes more than less visible ones ${ }^{5}$, even when they have the same value (Chetty, et al., 2009). Third, the isolation effect and the aggregation effect refer to people's failure to aggregate wins and losses in complex tax reforms and to look at the whole picture (McCaffery and Baron, 2003a, 2003b). A fourth bias is that people's perceived probabilities are distorted by desires, a phenomenon which McCaffery and Baron (2003a) refer to as wishful thinking. This may explain why people tend to believe subsidies are more effective than taxes to realise environmental goals, contrary to what studies find (Rienstra, Rietveld, \& Verhoef, 1999). A fifth relevant bias is the endowment effect, which refers to the fact that people tend to attach more value to the losses related to a tax reform than to the gains (Daugbjerg and Svendsen, 2003; Thaler, 1980). Hence, revenue-neutral reforms may not be sufficient to gain the public's approval for an environmental tax reform. The sixth bias is the so-called metric effect, which means that expressing an environmental tax in monetary terms (e.g. in euro) instead of a percentage change will reduce acceptability (Hsu, et al., 2008; McCaffery and Baron, 2003b). The seventh phenomenon is the role of framing. In the context of an ETR, an example of positive framing or labelling would be to avoid the word 'tax' and replace it by 'contribution', 'fee' or just a

\footnotetext{
${ }^{5}$ For example, a road toll tax with automatic payment by direct debit.
} 
description. Positive framing may entail increased support for an ETR (Brannlund and Persson, 2012; Kahneman and Tversky, 1984).

\section{Empirical literature on support for ET and ETR}

Several empirical studies have searched for determinants that help explain the support for environmental taxation. While a detailed systematic meta-analysis is beyond the scope of this paper, a multi-study comparison sheds light on the likely determinants of acceptance of ETX. A summary of the empirical literature is presented in the supplemental material (supplemental table 1).

The literature study suggests the following conclusions. First, evidence that socioeconomic and demographic variables determine support for ETX is inconclusive, with several studies finding contradictory results. Only education has a clear positive effect on support. Studies on the effect of income, age, gender, number of children and unemployment are inconclusive. Second, owning a car clearly influences one's acceptance of ETX. Some studies even find a proportional drop in support per car owned (Baranzini and Carattini, 2017; Thalmann, 2004). Third, people who distrust government are less likely to accept ETX. In addition to this general distrust, people often do not trust government to keep its promise to spend the revenues from an ETR on the environment. Fourth, people are sceptical about the potential of Pigouvian taxation to change people's behaviour in a more sustainable direction (effectiveness), and this arguably affects acceptability. Fifth, when an ETR is regressive in people's perception, they are less likely to be in favour of ETX. Sixth, public support for ETX, as for other environmental policy solutions, tends to differ according to the depth and specificity of the question in the reviewed studies' surveys. Expressed support for 'paying an environmental tax to solve environmental problems' is typically higher than for a specific tax such as higher fuel taxes. This may be explained by the fact that people do not think about concrete impacts or designs of environmental taxes before that concrete design is presented to 
them in a clear way with no room for misunderstanding (OECD, 2006). Another explanation maybe the role of salience (see section 2.2). A seventh conclusion is that empirical studies confirm the expected effect of framing or labelling (see section 2.2). Finally, empirical studies find evidence for some of the other theoretical claims (see sections 2.1 and 2.2), such as tax aversion, fiscal illusion, wishful thinking, salience, the metric effect, aggregation effect, framing and complexity.

The last set of important empirical results relate to the importance of recycling the revenues from an ETR. According to economic theory, adding the revenues to the general budget is the option that maximises welfare at the societal level (Parry, 1995). Government will then use these resources where it feels societal needs are the greatest, or - in economists' terms - where the highest welfare gains can be achieved. However, adding the tax proceeds to the general budget makes for a very unpopular policy package. Opposition against environmental taxes is significantly lower when the tax proceeds are returned to the tax payers ('revenue recycling'). Various ways of realising revenue recycling are available. We created a 'Ladder of Acceptability of Revenue Recycling Options' (LARRO) by putting six recycling options in declining order of acceptance, based on the available empirical literature:

(1) financing specific environmental programmes (also called earmarking or hypothecation);

(2) reducing taxes on labour, consumption, corporate income, property or other distortionary taxes. Such an environmental tax reform (ETR) may reduce the distortionary impacts of the green taxes and even produce net employment creation (the so-called double dividend) or other welfare gains;

(3) returning the additional taxes from one sector to that same sector in a way that is not proportional to the emissions, pollution or resource use (sector neutrality); output-based repayment is one example (Fischer, 2001).

(4) eliminating or mitigating regressive effects of the ETX; 
(5) lump-sum refund to the public;

(6) reducing public debt or adding to the general budget (which is strictly speaking not revenue recycling).

Several studies have revealed that the public is rather sceptical about recycling the revenues by lowering taxes in other policy fields, such as labour, in a revenue-neutral way. Instead, the recycling option that seems most acceptable to citizens, is the earmarking option: using the additional revenues for measures that clearly benefit the environment. However, several studies have concluded that earmarking decreases efficiency (Kallbekken and Aasen, 2010). These results point to the existence of a trade-off between efficiency and acceptability: the most efficient policy solutions get the lowest public support and vice versa (Amdur, Rabe, \& Borick, 2014; Bachus, 2017; Felder and Schleiniger, 2002; Rienstra, et al., 1999).

Economists refer to this type of preference as non-rational. Several studies have dug deeper into the explanations for this phenomenon. First, people find it very hard to understand the link between ETX and labour taxation; they do not see the logic behind it and therefore they reject it (Beuermann and Santarius, 2006; Thalmann, 2004). Second, people tend to be aware of the environmental tax side of the tax reform (the cost), but less aware of the fact that their labour taxes had gone down as well (the benefit) (Dresner, Dunne, Clinch, \& Beuermann, 2006). Third, even when explained that the government revenue would be fully recycled through lower labour taxes, many people do not believe it and reckon the reform will still, at the end of the day, fill government's pockets (Cherry, et al., 2014; Kallbekken, et al., 2011). The preference for earmarking is apparently related to the issue of trust (Anesi, 2006). Fourth, people are confused about the terminology related to ETR. The term 'ecological tax reform' is problematic, as both 'ecological' and 'tax' are negatively connotated, and it contains no reference to labour (Dresner, et al., 2006). Alternative framing and labelling could possibly increase support for an ETR (see section 2.2). 


\section{Hypotheses and data}

Based on the theoretical and empirical literature study, we propose three hypotheses, which next we test using a large-scale survey.

Hypothesis 1. Acceptance of and willingness to pay (WTP) for environmental taxes (ETX) is generally low, and lower for a specific tax (described in detail) than for environmental taxation in general (specificity hypothesis).

Hypothesis 2. Education and environmental concern are determinants of support for environmental taxes (ETX), while age, gender, income, unemployment, household size, home ownership and being religious are not.

Hypothesis 3. The six main revenue recycling options can be ranked as follows, in descending order of support:

a. Earmarking for the environment;

b. Lowering labour taxes (equal reduction of employer and employee social security contributions); this is the ETR-option;

c. Repayment to the economic sectors that face the highest risk of job losses owing to the ETX;

d. Lump sum repayment to the public;

e. Lowering corporate income taxation (company profit tax)

f. Government debt reduction/general budget

We call this hierarchy the 'Ladder of Acceptability of Revenue Recycling Options (LARRO)'

The empirical analysis in this paper is based on LEVO 2012, a survey conducted in Flanders, the northern part of Belgium. LEVO is the Dutch acronym for 
'LEvensomstandigheden in Vlaanderen Onderzocht' (research on living conditions in Flanders). It is an annual large-scale survey organised in the framework of a research seminar at the economics faculty of Ghent University. The fieldwork is carried out by master's students, while the organization, supervision, controlling and cleaning is performed by the authors. The main subject of the survey was living conditions and wellbeing but several questions were added on the topic of acceptance of ETX. The survey used quota sampling and data was gathered from 1308 respondents. The data are statistically weighted to obtain a sample that is representative of the Flemish population in terms of employment situation, gender and age.

The data include socioeconomic and demographic characteristics such as age, gender, having a relationship, home ownership, health, number of children, income and being religious. For income, a distinction was made between objective income (in euro) and subjective income, which was a self-assessment scale ranging from 0 'completely disagree' to 10 'completely agree' for the position 'My (household) income is sufficient to live well'.

A question on the degree to which material expectations are met (a percentage between 0 and 100) offered an alternative wealth indicator. Finally, the survey contained questions related to a self-rating on twelve personality traits on a numeric 7-point scale: extrovert, altruistic, conscientious-dutiful, worried, hard to please, creative, optimistic, self-confident, emotional, progressive, jealous and having high expectations.

Finally, the questionnaire contained two questions related to environmental concern: 'Do you think government is doing enough to tackle environmental problems?' and 'Do you see climate change as a problem?'. Both questions had five-point Likert response scales.

The results of the survey as discussed in the following sections are valid only for the Flemish region and may differ if the same questions are asked in other geographical areas. 


\section{Results and discussion}

\section{Support and WTP for environmental taxes}

The questionnaire contained one question on the respondents' general acceptance of ETX and one question on the acceptability of a specific carbon tax. We chose to use a carbon tax as the specific environmental tax because - after we mentioned that this tax will be levied on all energy products - this tax is relatively straightforward for respondents to understand and imagine its impact. We note that the results may differ if another tax is selected as the specific environmental tax

The results are presented in table 1 .

Table 1. Support for the general principle of ET and for a specific carbon tax (\%)

\section{Link to table 1}

Nearly half of the respondents support the general idea of environmental taxation. Support declines to $35 \%$ when the tax is specified as a carbon tax that will raise energy prices. A Wilcoxon Rank test indicates that this difference is statistically significant $(p=0.000)$. Consequently, our first research hypothesis, the specificity hypothesis, is confirmed. This result is important, because in reality the details of any announced environmental tax will be actively divulged by either the government or the opponents of the tax (Gaunt, Rye, \& Allen, 2007). Therefore, the survey result for the specific tax is a better predictor for real-life support than the general environmental tax result.

A third question directly gauged people's willingness to pay a carbon tax on energy, by asking which rise of the monthly energy bill people would find acceptable (table 2).

Table 2. Willingness to pay a carbon tax on energy (€/month rise of the energy bill) 


\section{Link to table 2}

The willingness to pay is low: $30 \%$ does not accept a higher energy bill, while $44 \%$ is willing to pay (only) $€ 10$. This result is in line with other studies and with the answers to the two support questions. It also confirms the existence of a trade-off between acceptability and efficiency ${ }^{6}$, as was found in section 2.3. Note that in this stage, revenue recycling was not mentioned in the questionnaire.

To examine the link between support and willingness to pay, we construct a high support and a low support group for the two support questions. People who are 'rather in favour' or 'strongly in favour' of the tax are classed in the 'high support group' for that type of tax. Those who are 'rather opposed' or 'strongly opposed' to the tax end up in the 'low support group'. The four answering possibilities are combined in table 3. A large majority (73\%) is consistently in favour of or opposed to both taxes. A Bonferonni post hoc test indicates that all pairwise comparisons of averages are significantly different $(\mathrm{p}=0,000)$ except for the two differentiated categories (low support for one and high for the other). Moving from low to differentiated, the WTP doubles, and then from differentiated to high support for both taxes, the WTP triples compared to the low support group. This result provides support for the assumption made in the introduction that WTP can be regarded as an indirect measure of support for environmental taxation.

Table 3. Mean WTP in terms of acceptance of general and specific environmental taxes

\section{Link to table 3}

\footnotetext{
${ }^{6}$ This conclusion is drawn based on our own empirical findings on acceptability and findings in literature on the efficiency of different recycling options (Amdur, et al., 2014; Felder and Schleiniger, 2002; Kallbekken and Aasen, 2010; Rienstra, et al., 1999).
} 


\section{Determinants of WTP and support for ETX}

Table 4 shows which variables are important for understanding the inter-individual variation in the WTP. We perform an ordinary least square (OLS) regression using the maximum amount as dependent variable (e.g. for those indicating they want to pay maximum $€ 10$, the WTP variable equals $€ 10$ ). The selection of variables in the OLS model is based on bivariate significance tests. This means that several standard socioeconomic variables are not selected for the final model because they are not significant: age (and age square), gender, personality, education of the mother, having a relation, having children, being religious and being in good health. Objective income (in euro) and education are both significant, but since they are strongly correlated and education is more important than objective income, only education (years of schooling) is included in the model and objective income is not. Subjective income (selfassessment, income is sufficient to live well) is more significant than objective income and more independent from education, so it is selected for the model. Furthermore, the variable 'material expectations realized', as a proxy for 'wealth', is added to the model. Finally, we included some variables related to environmental concern. We create two dummies for the opinion whether government is doing enough for the environment: too little effort and too much effort; the reference category is 'adequate effort'. To capture the opinion of respondents on global warming, we add a dummy for those who consider it as a (big) problem; the reference category is 'minor problem or deny the issue'.

Table 4. Ordinary least squares (OLS) estimates for WTP an ETX

\section{Link to table 4}

All variables in the OLS regression model are significant, which means that they influence the WTP for ETX. The table should be read as follows:

- $\quad$ each additional year of schooling increases WTP by $€ 0.56$; 
- each point that subjective income is rated higher (on a 1 to 10 scale) increases WTP by $€ 0.84$

- $\quad$ each percentage point that material expectations are more met increases WTP by $€ 0.56$;

- the WTP of respondents who think that government is not doing enough to protect the environment is $€ 1.90$ higher compared to those who think government is doing enough;

- the WTP of respondents who think that government is doing too much to protect the environment is $€ 4.09$ lower compared to those who think government is doing enough;

- $\quad$ the WTP of respondents who consider global warming as a (big) problem is $€ 3.19$ higher compared to those who think it is a minor problem or who deny the issue.

The conclusion from the standardised coefficients analysis is that education is the most important determinant of WTP.

Further testing using an ordinal logit model with the same variables provides similar results. ${ }^{7}$ Our analysis provides evidence to confirm our second hypothesis: education, income and environmental concern are determinants of support or WTP for ETX, whereas most other socio-demographic variables are not. These results are in line with the findings of other studies, although many other studies were inconclusive on the effect of income. In this study, we found a small positive effect of income expressed in monetary terms and a stronger effect of the subjective parameter of having an income that is 'sufficient to live well'.

\section{Support for Environmental Tax Reform (ETR)}

Environmental taxes are aimed at inducing behavioural responses benefiting the environment. However, they also generate revenue, which could be 'recycled' to 'compensate' for the taxes. Seven such revenue recycling options were presented to the participants of the survey.

\footnotetext{
7 These results can be obtained from the authors on request
} 
Table 5 shows that the highest support goes to the two earmarking options, in which the revenues of the environmental taxes are spent on environmental policies. The option of 'investments in renewable energy' receives the highest support, closely followed by the option 'actions to improve the climate or the environment'. The ETR receives lower support but remains a popular recycling option in the eyes of the survey participants. The relatively small difference in acceptability between earmarking and ETR is also found by Thalmann (2004) but Baranzini and Carattini (2017) find a larger difference. Behind these three preferred options, acceptability drops sharply for public debt reduction, lump sum repayments and specific sector refunds. Finally, reducing corporate taxation is the least preferred option by far for the participants.

To test whether the average support for the alternatives differs significantly, a pairwise comparison is performed. The p-values of the Wilcoxon rank test are provided in the last column of table 5, each time compared to the alternative in the line above.

Table 5. Public support for different compensating mechanisms (\%)

\section{Link to table 5}

The results largely support our third hypothesis regarding the 'Ladder of Acceptability of Revenue Recycling Options (LARRO)'. Only the option of reducing public debt is ranked higher than in most other empirical studies. A speculative explanation for this difference may lie in the fact that Belgium is a 'debt-burdened' country, with public debt exceeding $103 \%$ of GDP in 2017 (Belgian Debt Agency, 2018). Another hypothesis is that our phrasing of this option as 'debt reduction', may be more acceptable to the public than the option 'adding to the general budget'. Future research could provide a clearer answer to this question. 


\section{Conclusion}

In this paper, we examined the determinants and the conditions of public support for environmental taxation and environmental tax reform. Most of the empirical insights are immediately policy relevant and can instantly be translated into policy recommendations. Therefore, the main conclusions of this paper are presented as a recommended policy package, based on both our own empirical conclusions and on findings from other studies.

This paper has shown that ETX and ETR are delicate operations from the perspective of public acceptance. However, the trade-off between acceptability (earmarking) and efficiency (ETR) can significantly be abated by designing an ETR with the following six characteristics. First (and foremost), a part of the tax revenues should be spent on improving the environment, but not too much as this hollows out efficiency. Second, many studies indicate that significant time and budget should be spent on communicating the ETR, with a focus on highlighting the benefits to the public of both the ETX side (environmental improvement; highlighting the costs of inaction) and the revenue spending side (the ETR). Specific attention should be given to preparatory (independent) studies providing evidence for the environmental effectiveness of the environmental tax. This study should be communicated in a way that it reaches a large public, using language that is understandable to all. Third, providing specificity on the ETX is unavoidable. Trust in the government's good intentions with the tax reform may be enhanced by providing full transparency and coherence, both in the design and throughout the policy process of ETR. Moreover, specificity and salience on the revenue spending side should be a target. For example, a reduction of labour taxes could be mentioned explicitly on monthly salary slips and the annual tax assessment for reasons of salience. Tax increases are to be communicated in percentages, and tax reductions in absolute currency. Fourth, to overcome the endowment effect observed in literature, the whole operation could be made 'more than revenue-neutral', i.e. creating a net cost for government. Fifth, studies have observed that 
spending part of the revenues to mitigate the regressive impact of the ETR will increase acceptability. Sixth, the possibility of a trial period and a 'threshold Pigouvian tax' instead of a regular tax could be studied and considered. At the same time, these additions should not increase complexity too much: the more complex the ETR, the less likely it will be supported by the public.

In this study, several hypotheses were tested and variables were identified that may determine or explain support for a green tax reform. However, the study has also demonstrated that public acceptability and ETR are complex phenomena, and despite the multitude of existing studies, many potential determinants and design improvements have not (yet) been uncovered or fully understood. There is a need for a better understanding of the acceptability conditions of ETR. An experimental study on the effectiveness of measures or design choices that tackle the efficiency-acceptability trade-off could aim at transforming an 'efficient but unacceptable' ETR into an 'efficient and acceptable' one. Furthermore, future empirical studies could shed a light on the role of co-benefits of a carbon tax, on ways to convince the public of the effectiveness of environmental taxation, and on the potential of innovative policy mixes, including threshold taxation, trial periods and bonus-malus systems. Finally, knowledge on the Ladder of Acceptability of Revenue Recycling Options (LARRO) could be expanded by adding smart policy mixes to the recycling options. 


\section{References}

Aidt, T. S. (2010). Green taxes: Refunding rules and lobbying. Journal of Environmental Economics and Management, 60(1), pp. 31-43. doi:http://dx.doi.org/10.1016/i.jeem.2010.04.001 retrieved from http://www.sciencedirect.com/science/article/pii/S0095069610000410

Amdur, D., Rabe, B. G., \& Borick, C. (2014). Public Views on a Carbon Tax Depend on the Proposed Use of Revenue. Issues in Energy and Environmental Policy, July 2014, 9.

Anesi, V. (2006). Earmarked taxation and political competition. Journal of Public Economics, 90(4-5), pp. 679-701. doi:http://dx.doi.org/10.1016/i.jpubeco.2005.03.005 retrieved from http://www.sciencedirect.com/science/article/pii/S0047272705000733

Attari, S. Z., Schoen, M., Davidson, C. I., DeKay, M. L., Bruine de Bruin, W., Dawes, R., \& Small, M. J. (2009). Preferences for change: Do individuals prefer voluntary actions, soft regulations, or hard regulations to decrease fossil fuel consumption? Ecological Economics, 68(6), pp. 17011710. doi:http://dx.doi.org/10.1016/i.ecolecon.2008.10.007 retrieved from http://www.sciencedirect.com/science/article/pii/S0921800908004692

Avi-Yonah, R. S. (2007). The Three Goals of Taxation. Tax Law Review, 60(1), pp. 1-28.

Avi-Yonah, R. S. (2010). Taxation as Regulation: Carbon Tax, Health Care Tax, Bank Tax and Other Regulatory Taxes. University of Michigan Program in Law and Economics. Working Paper 21.

Avi-Yonah, R. S., \& Uhlmann, D. M. (2009). Combating Global Climate Change: Why a Carbon Tax is a Better Response to Global Warming than Cap and Trade. Stanford Environmental Law Journal, 28(3), p 49.

Bachus, K. (2017). The use of environmental taxation as a regulatory policy instrument. PhD dissertation. University of Leuven, Leuven.

Baranzini, A., Caliskan, M., \& Carattini, S. (2014). Economic Prescriptions and Public Responses to Climate Policy. Cahiers de recherche du Centre de Recherche Appliquée en Gestion (CRAG) de la Haute Ecole de Gestion, Genève, HES-SO/HEG-GE/C-14/3/1-C

Baranzini, A., \& Carattini, S. (2017). Effectiveness, earmarking and labeling: testing the acceptability of carbon taxes with survey data. [journal article]. Environmental Economics and Policy Studies, 19(1), pp. 197-227. doi:10.1007/s10018-016-0144-7 retrieved from http://dx.doi.org/10.1007/s10018-016-0144-7

Baumol, W., \& Oates, W. E. (1988). The Theory of Environmental Policy (2 ed.) Cambridge: Cambridge University Press.

Belgian Debt Agency (2018). Review 2018 and Outlook 2018. Brussels

Beuermann, C., \& Santarius, T. (2006). Ecological tax reform in Germany: handling two hot potatoes at the same time. Energy Policy, 34(8), pp. 917-929. 
doi:http://dx.doi.org/10.1016/i.enpol.2004.08.045

Brannlund, R., \& Persson, L. (2012). To tax, or not to tax: preferences for climate policy attributes. Climate Policy, 12(6), pp. 704-721. doi:10.1080/14693062.2012.675732 retrieved from http://dx.doi.org/10.1080/14693062.2012.675732

Buchanan, J. M., \& Tollison, R. (1984). Politics Without Romance: A Sketch of Positive Public Choice Theory and Its Normative Implications. In J. M. Buchanan \& R. Tollison (Eds.), The Theory of Public Choice. Ann Arbor: Publishing Michigan.

Caplan, B. (2007). The myth of the rational voter: why democracies choose bad policies Washington DC: Princeton University Press.

Cherry, T. L., Kallbekken, S., \& Kroll, S. (2014). The impact of trial runs on the acceptability of environmental taxes: Experimental evidence. Resource and Energy Economics, 38, pp. 84-95. doi:http://dx.doi.org/10.1016/j.reseneeco.2014.06.005 retrieved from http://www.sciencedirect.com/science/article/pii/S092876551400058X

Cherry, T. L., Kallbekken, S., \& Kroll, S. (2017). Accepting market failure: Cultural worldviews and the opposition to corrective environmental policies. Journal of Environmental Economics and Management, 85, pp. 193-204. doi:https://doi.org/10.1016/i.jeem.2017.05.004 retrieved from http://www.sciencedirect.com/science/article/pii/S0095069617303121

Chetty, R., Looney, A., \& Kroft, K. (2009). Salience and Taxation: Theory and Evidence. American Economic Review, 99(4), pp. 1145-1177. doi:10.1257/aer.99.4.1145 retrieved from http://www.aeaweb.org/articles?id=10.1257/aer.99.4.1145

Clinch, J. P., Dunne, L., \& Dresner, S. (2006). Environmental and wider implications of political impediments to environmental tax reform. Energy Policy, 34(8), pp. 960-970. doi:http://dx.doi.org/10.1016/i.enpol.2004.08.048 from http://www.sciencedirect.com/science/article/pii/S030142150400285X

Coase, R. H. (1960). The Problem of Social Cost. The Journal of Law and Economics, 3, pp. 1-44. doi:doi:10.1086/466560 retrieved from http://www.journals.uchicago.edu/doi/abs/10.1086/466560

Cullis, J. G., \& Jones, P. R. (1998). Towards a "New" outrageous public choice. The Journal of SocioEconomics, 27(5), pp. 623-640. doi:http://dx.doi.org/10.1016/S1053-5357(99)80115-2 retrieved from http://www.sciencedirect.com/science/article/pii/S1053535799801152

Daugbjerg, C., \& Svendsen, G. T. (2003). Designing green taxes in a political context: from optimal to feasible environmental regulation. Environmental Politics, 12(4), pp. 76-95. doi:10.1080/09644010412331308384 retrieved from http://dx.doi.org/10.1080/09644010412331308384

Dresner, S., Dunne, L., Clinch, P., \& Beuermann, C. (2006). Social and political responses to ecological tax reform in Europe: an introduction to the special issue. Energy Policy, 34(8), pp. 895-904. 
doi:10.1016/j.enpol.2004.08.043

retrieved

from

http://www.sciencedirect.com/science/article/pii/S0301421504002794

Felder, S., \& Schleiniger, R. (2002). Environmental tax reform: efficiency and political feasibility. Ecological Economics, 42(1-2), pp. 107-116. doi:http://dx.doi.org/10.1016/S09218009(02)00109-X retrieved from http://www.sciencedirect.com/science/article/pii/S092180090200109X

Fischer, C. (2001). Rebating Environmental Policy Revenues: Output-Based Allocations and Tradable Performance Standards.

Franzen, A., \& Meyer, R. (2010). Environmental Attitudes in Cross-National Perspective: A Multilevel Analysis of the ISSP 1993 and 2000. European Sociological Review, 26(2), pp. 219-234. doi:10.1093/esr/jcp018 retrieved from http://dx.doi.org/10.1093/esr/icp018

Gaunt, M., Rye, T., \& Allen, S. (2007). Public Acceptability of Road User Charging: The Case of Edinburgh and the 2005 Referendum. Transport Reviews, 27(1), pp. 85-102. doi:10.1080/01441640600831299 retrieved from http://dx.doi.org/10.1080/01441640600831299

Green Fiscal Commission (2009). Doing What it Takes to Reduce Carbon Emissions: The Case for Green Fiscal Reform. London

Heres, D., Kallbekken, S., \& Galarraga, I. (2013). Understanding Public Support for ExternalityCorrecting Taxes and Subsidies: A lab experiment. BC3 Working Paper Series, 2013(4).

Hood, C. C. (1983). The Tools of Government London and Basingstoke: Macmillan Press.

Houdek, P., \& Koblovský, P. (2015). Where is My Money? New Findings in Fiscal Psychology. Society, 52(2), pp. 155-158. doi:10.1007/s12115-015-9873-7 retrieved from https://doi.org/10.1007/s12115-015-9873-7

Hsu, S.-L., Walters, J., \& Purgas, A. (2008). Pollution tax heuristics: An empirical study of willingness to pay higher gasoline taxes. Energy Policy, 36(9), pp. 3612-3619. doi:http://dx.doi.org/10.1016/j.enpol.2008.06.010 retrieved from http://www.sciencedirect.com/science/article/pii/S0301421508002991

Ivanova, G., \& Tranter, B. (2004, 29 Sept. - 1 October 2004). Willingness to Pay for 'the Environment' in Cross-National Perspective. Australasian Political Studies Association Conference, Adelaide.

Kahneman, D. (2003). Maps of Bounded Rationality: Psychology for Behavioral Economics. American Economic Review, 93(5), pp. 1449-1475. doi:doi: 10.1257/000282803322655392 retrieved from http://www.aeaweb.org/articles?id=10.1257/000282803322655392

Kahneman, D., \& Tversky, A. (1984). Choices, Values and Frames. American Psychologist, 39(4), pp. 341-350. 
Kallbekken, S., \& Aasen, M. (2010). The demand for earmarking: Results from a focus group study. Ecological Economics, 69(11), pp. 2183-2190. doi:10.1016/j.ecolecon.2010.06.003 retrieved from http://www.sciencedirect.com/science/article/pii/S0921800910002284

Kallbekken, S., Kroll, S., \& Cherry, T. L. (2011). Do you not like Pigou, or do you not understand him? Tax aversion and revenue recycling in the lab. Journal of Environmental Economics and Management, 62(1), pp. 53-64. doi:http://dx.doi.org/10.1016/j.jeem.2010.10.006 retrieved from http://www.sciencedirect.com/science/article/pii/S0095069611000192

McCaffery, E. J., \& Baron, J. (2003a). Heuristics and Biases in Thinking about Tax. Center for the Study of Law and Economics Working Paper.

McCaffery, E. J., \& Baron, J. (2003b). The Humpty Dumpty blues: Disaggregation bias in the evaluation of tax systems. Organizational Behavior and Human Decision Processes, 91(2), pp. 230-242. doi:http://dx.doi.org/10.1016/S0749-5978(03)00026-8 retrieved from http://www.sciencedirect.com/science/article/pii/\$0749597803000268

Meier, K. J. (1985). Regulation: Politics, Bureaucracy, and Economics New York: St. Martin's Press.

Melis, G., Elliot, M., \& Shryane, N. (2014). Environmental Concern Over Time: Evidence from the Longitudinal Analysis of a British Cohort Study from 1991 to 2008*. Social Science Quarterly, 95(4), pp. 905-919. doi:10.1111/ssqu.12107 retrieved from http://dx.doi.org/10.1111/ssqu.12107

Newell, R. G., \& Pizer, W. A. (2003). Regulating stock externalities under uncertainty. Journal of Environmental Economics and Management, 45, pp. 416-432.

Nordhaus, W. D. (2007). To Tax or Not to Tax: Alternative Approaches to Slowing Global Warming. Review of Environmental Economics and Policy, 1(1), pp. 26-44. doi:10.1093/reep/rem008 retrieved from http://reep.oxfordjournals.org/content/1/1/26.abstract

OECD (1997). Environmental Taxes and Green Tax Reform Paris: OECD Publishing.

OECD (2006). The Political Economy of Environmentally Related Taxes Paris: OECD Publishing.

Oh, C., \& Svendsen, G. T. (2015). Command-And-Control or Taxation? The Cases of Water Regulation in California and Denmark. 2015, 4(2), p 11. doi:10.5296/emsd.v4i2.8358 retrieved from http://www.macrothink.org/journal/index.php/emsd/article/view/8358/6786

Pagiaslis, A., \& Krontalis, A. K. (2014). Green Consumption Behavior Antecedents: Environmental Concern, Knowledge, and Beliefs. Psychology \& Marketing, 31(5), pp. 335-348. doi:10.1002/mar.20698 retrieved from http://dx.doi.org/10.1002/mar.20698

Parry, I. W. H. (1995). Pollution Taxes and Revenue Recycling. Journal of Environmental Economics and Management, 29(3), pp. S64-S77. doi:10.1006/jeem.1995.1061 retrieved from http://www.sciencedirect.com/science/article/pii/\$0095069685710613 
Perman, R., Common, M., Maddison, D., \& McGrilvray, J. (2003). Natural Resource and Environmental Economics Harlow: Pearson Education.

Peters, B. G. (1991). The Politics of Taxation: A Comparative Perspective Cambridge: Blackwell.

Pigou, A. C. (1920). The Economics of Welfare London: MacMillan.

Rienstra, S. A., Rietveld, P., \& Verhoef, E. T. (1999). The social support for policy measures in passenger transport. A statistical analysis for the Netherlands. Transportation Research Part D, 1999(4), pp. 181-200.

Simon, H. A. (1955). A Behavioral Model of Rational Choice. The Quarterly Journal of Economics, 69(1), pp. 99-118. doi:10.2307/1884852 retrieved from http://www.jstor.org/stable/1884852

Steg, L., Dreijerink, L., \& Abrahamse, W. (2006). Why are Energy Policies Acceptable and Effective? Environment and Behavior, 38(1), pp. 92-111. doi:10.1177/0013916505278519 retrieved from http://journals.sagepub.com/doi/abs/10.1177/0013916505278519

Stern, P. C., Dietz, T., \& Kalof, L. (1993). Value Orientations, Gender, and Environmental Concern. Environment and Behavior, 25(5), pp. 322-348. doi:10.1177/0013916593255002 retrieved from http://iournals.sagepub.com/doi/abs/10.1177/0013916593255002

Thaler, R. (1980). Toward a positive theory of consumer choice. Journal of Economic Behavior \& Organization, 1(1), pp. 39-60. doi:http://dx.doi.org/10.1016/0167-2681(80)90051-7 retrieved from http://www.sciencedirect.com/science/article/pii/0167268180900517

Thalmann, P. (2004). The Public Acceptance of Green Taxes: 2 Million Voters Express Their Opinion. Public Choice, 119(1-2), pp. 179-217. doi:10.1023/B:PUCH.0000024165.18082.db retrieved from http://dx.doi.org/10.1023/B\%3APUCH.0000024165.18082.db

Vandyck, T., \& Van Regemorter, D. (2014). Distributional and regional economic impact of energy taxes in Belgium. Energy Policy, 72, pp. 190-203. doi:http://dx.doi.org/10.1016/i.enpol.2014.04.004 retrieved from http://www.sciencedirect.com/science/article/pii/S0301421514002122

Vedung, E. (1998). Policy Instruments: Typologies and Theories. In M.-L. Bemelmans-Videc, R. C. Rist \& E. Vedung (Eds.), Carrots, Sticks \& Sermons. Policy Instruments \& Their Evaluation (pp. 21-58). New Brunswick-London: Transaction Publishers.

Wagner, R. E. (1976). Revenue Structure, Fiscal Illusion, and Budgetary Choice. Public Choice, 25, pp. 45-61. retrieved from http://www.jstor.org.kuleuven.ezproxy.kuleuven.be/stable/30022857

Zhang, K., Wang, Q., Liang, Q.-M., \& Chen, H. (2016). A bibliometric analysis of research on carbon tax from 1989 to 2014. Renewable and Sustainable Energy Reviews, 58, pp. 297-310. doi:https://doi.org/10.1016/j.rser.2015.12.089 from http://www.sciencedirect.com/science/article/pii/S1364032115014720 